\title{
Vultures attacking livestock: a problem of vulture behavioural change or farmers' perception?
}

\author{
OLIVIER DURIEZ (D), SANDRINE DESCAVES, REGIS GALLAIS, \\ RAPHAËL NEOUZE, JULIE FLUHR and FREDERIC DECANTE
}

\section{Summary}

Human-wildlife conflicts are often partly due to biased human perceptions about the real damage caused by wildlife. While Griffon Vultures Gyps fulvus are obligate scavengers, 156 complaint reports about vultures attacking livestock were officially recorded over eight years (2007-2014) in France. We investigated whether this conflict could be explained by a change in vulture behaviour, or by a biased perception by farmers. If vultures became predators, as a consequence of density-dependent processes, we predicted that reports would concern mostly ante-mortem consumption of healthy livestock and would be temporally and spatially correlated to vulture population size and space use. Under the hypothesis of perception bias of farmers, we predicted that reports would concern mostly post-mortem consumption, and would be more numerous in areas where farmers are less familiar with vultures and where herds are less attended by shepherds. The spatio-temporal distribution of reports was not correlated with the vulture's population trend and was not centred on the core area of vulture home range. In $67 \%$ of reports, vultures consumed post-mortem an animal that had died for other reasons. In $18 \%$ of reports, vultures consumed ante-mortem an animal that was immobile and close to death before vulture arrival. The fact that $90 \%$ of complaining farmers did not own vulture supplementary feeding stations and that $40 \%$ of these farms were located outside protected areas (where most education programmes take place) suggests that most farmers had little familiarity or personal knowledge of vultures. There was no shepherd witness present in $95 \%$ of the reports. Therefore, the hypothesis of a perception bias due to lack of knowledge was most likely to explain this vulture-livestock conflict rather than the hypothesis of a recent change in vulture feeding behaviour. Environmental education should be better included in conservation programmes and enhanced in areas where vultures are expanding to recolonise their former distribution range.

\section{Introduction}

Conflicts between humans and wildlife are common (Redpath et al. 2015), becoming particularly acute when carnivores become competitors with people for game species and predators of domestic livestock and when predators are returning (naturally or helped by humans) after being absent for several years or decades (Woodroffe et al. 2005). In birds, such conflicts mostly concern piscivorous birds - such as herons or cormorants - in conflict with fisheries, and raptors in conflict with hunters or livestock farmers (Nyhus 2016). Yet the perception of conflict is often not correlated with the real predation rate, as has been shown with Bonelli's eagle Aquila fasciata that hunters perceive as a competitor for game (Moleón et al. 2011, Donázar et al. 2016). Overall, in conflicts between people and carnivores, the perceived impacts often exceed the actual evidence of 
conflict (Cavalcanti et al. 2010, Thorn et al. 2012). Perception can be defined as the way an individual observes, understands, interprets and evaluates a referent object or action (Bennett 2016). Perceptions are built by multiple contextual factors: culture, past experience, individual and collective attributes, values, norms, beliefs, knowledge, and are sometimes exacerbated by the media (Bennett 2016).

Obligate scavengers (i.e. vultures) generally induce little conflict with people since they feed exclusively on dead animals. Though in the absence of a witness to the death of an animal, scavengers (facultative or obligate) can be easily accused of having killed an animal on which they are found feeding, while the cause of death could be unrelated (Marr et al. 1995, Goldstein et al. 2006, O'Rourke 2014). Hence scavengers can also be victims of a perception bias, when they are perceived as predators while they consumed a prey killed by another animal or that died for miscellaneous reasons. Vultures have been allies of farmers in recycling carcasses of domestic animals since ancient times (Gangoso et al. 2013, Moleon et al. 2014, Campbell 2015, Cortès-Avizanda et al. 2015). Yet reports of vultures attacking livestock are regularly publicised in the media, describing a change in vulture behaviour, hypothesising that scavengers can become predators. Such reports concerned both New World Vultures such as Black Vulture Coragyps atratus (Avery and Cummings 2004) as well as Old World vultures such as Eurasian Griffon Vulture Gyps fulvus (Margalida et al. 2011). Regarding the latter species, complaints about attacks on living animals started in Spain in the 1990s (Camiña 1995). Increasing until 2006, these complaints extended to the French Pyrenees in the 2000s ( Donázar et al. 2009, Arthur and Zenoni 2010, Margalida et al. 2014).

In the Grands Causses (Massif Central, France), Griffon Vultures disappeared in the 1940s, but since 1981 the species has been successfully reintroduced, reaching $>300$ pairs in the 2010 (Terrasse et al. 2004; Duriez and Issa 2015). In this region, vultures are generally well accepted by farmers who manage 1oo supplementary feeding stations (SFS) to provide carcasses of naturally dead livestock (Dupont et al. 2012, Fluhr et al. 2017). Nevertheless in 2007 some farmers began to complain about interactions between vultures and livestock, generally referred as "attacks" by vultures.

The aim of the present study was to investigate I) whether vultures changed their behaviour, with a higher frequency of individuals acting as predators instead of scavengers; 2 ) if so, to what extent, both geographically and demographically (i.e. the proportion of the vulture population it would represent)? 3) if not, can a perception bias by farmers explain the spread of rumours of 'predatory' vultures? For this purpose, we analysed a database of 156 official reports collected between 2007 and 2014 (see Methods), that we combined with information about vulture population dynamics and movements, and the regional context of husbandry practices and the management of quartering.

To tackle the first aim on whether vultures modified their behaviour, or more precisely the change in occurrence of predatory events, we used veterinary expert assessments to determine the role of vultures in each interaction. In particular we examined if the interaction occurred before or after the death of livestock, and whether vultures acted as the primary, aggravating, or ancillary cause of death (which can only be assessed properly by vets, not by farmers). If the hypothesis of vultures acting as predators was true, we would expect a higher proportion of primary or aggravating factors (i.e. on healthy livestock, with a favourable vital diagnostic) compared to ancillary causes (immobile livestock with an unfavourable vital diagnostic) (see definitions in Methods). Second, we compared the spatio-temporal distribution of reports in relation to vulture demography and foraging behaviour. If predatory behaviour increased in frequency among vultures, our predictions were that 1 ) the temporal distribution of the number of reports should be correlated with vulture population trends, and 2) the spatial distribution of reports would be denser in the areas most intensively used by vultures, although hungry vultures can increase their foraging range (Spiegel et al. 2013).

The alternative hypothesis (hereafter called "Perception bias of conflict") could be that complaints are the result of the misinterpretation of the natural feeding behaviour of vultures, acting as scavengers on an animal already dead, and whose cause of death was not observed by the complainer. We tested this hypothesis in two ways, using indirect clues. First, the likelihood of observing 
the cause of death of livestock is likely to be related with husbandry practices, in particular whether the shepherd is usually present with the herd. Second, the level of knowledge of farmers about vultures should be correlated with the amount of information they received through communication actions, and their personal experience and familiarity with vultures. Most communications about vultures are conveyed through information from the local national and natural parks sent to farmers inhabiting these parks (Appendix S2 in the online Supplementary Material), and when farmers ask permission to establish an official SFS (Appendix S4). We thus considered the location of the report as an indirect clue to the familiarity of the farmer with vultures (personal experience) and the amount of information he/she might have received from trustworthy sources ( $1-2$ letters of information per year if they live in protected areas; Appendix S4). Our prediction was that if reports were mostly located outside protected areas, away from the colonies, and if shepherds did not visit their herd regularly and/or did not own an SFS, the complaints about "attacks" of vultures on livestock are very likely to reflect a "perception bias" rather than a true modification in vulture behaviour.

\section{Methods}

\section{Study area}

We focused on a region of southern France called "Grands Causses", characterised by limestone plateaux (mean elevation: 1,00o $\mathrm{m}$ ) intersected by canyons where vultures breed in colonies. Agriculture mostly consists of extensive sheep farming, with livestock grazing from April to October (although in the north and west of the Causses, livestock mostly consists of cattle and a few horses). Livestock numbers remained stable before and during the study period (2007-2014) (unpublished data from Comité Interdépartemental Vautours-Elevage 2018). The region encompasses three protected areas that include farmland: the Cevennes National Park (PNC), the Grands Causses Natural Regional Park (PNRGC) and the Haut Languedoc Natural Regional Park (PNRHL) (Appendix SI).

\section{Organisation of reports and vet assessments}

To understand the phenomenon and eventually propose solutions (e.g. financial compensation), state authorities launched an observatory, coordinated by a "Vulture-Livestock interaction committee", to describe the circumstances of complaints (i.e. geographical distribution, husbandry practices, state of livestock herd) and the role of vultures in the cause of livestock death. Between 2007 and 2014, 182 complaints were recorded into official reports (hereafter called "reports") by wildlife rangers. When a farmer suspected mortality among his herd to be attributable to vultures, he had to call a state ranger, who would appoint a veterinary surgeon, when available (see below and Appendix S2). The ranger asked the farmer to cover the remains of the carcass with a blanket (to stop vulture activity) and to leave it in the field until his arrival (within 24 hours), to preserve as many clues as possible. The ranger's role was to question the farmer about the circumstances of the complaint, and to collect potential evidence of vulture presence (e.g. feathers, blood, stamped grass).

When possible, an independent expert assessment was performed by a veterinary officer specially trained to determine the conditions of livestock death based upon field clues and carcass autopsy (hereafter called "vet assessment"). The veterinary surgeon was independent from the farm and the vet availability was not correlated with protected areas. The vet surgeon was expert on exploring the carcass to search for elements that could explain the death (e.g. injuries, internal or pathological lesions, haemorrhages, marks of claws, beak or tooth). The veterinary surgeon established the diagnostic (what was the health state of the animal prior to vulture intervention?) and the prognostic (what was its probability of survival prior to vulture intervention, given the diagnosed pathology or difficulty?) of the animal. Because the loss of mobility is likely to be an important stimulus for vultures, the investigation focused on assessing the level of the animal's 
mobility prior to the intervention of vultures. The interaction factors of vultures were ranked into five categories: quartering, primary, aggravating, ancillary and injury, as explained in Table 1 . When the vet surgeon could not conclude with certainty, the case was marked as "not assessable". We compiled all official reports and vet assessments recorded in the Grands Causses between 2007 and 2014. Each report site was georeferenced in GIS (Quantum-GIS 2.18).

\section{Vulture monitoring data}

Since the start of Griffon Vulture reintroduction in 1981, every nest site was monitored once a week throughout the breeding season (from January to July). The presence of any incubating adult or chick was recorded until the fledging period and an accurate number of nests with eggs was estimated using as a proxy of the number of breeding pairs. Because vulture nests are scattered along $40 \mathrm{~km}$ of canyons, in four valleys, for the sake of simplicity, we defined the aviaries used for the reintroduction as the centre of the colonies, being located near the barycentre of the nests (all nests then being located in a c.1o km radius).

Since 2010-2011, we tracked 25 individual vultures (20 adults and 5 immature birds) by GPS telemetry simultaneously, and the number of tagged vultures progressively reduced (due to tag loss, tag failure, recapture or death of some birds) until 2014 when the last four vultures remained. We assume that the movements of these 25 birds were most likely to represent the behaviour of the whole population. Individual home ranges have been estimated yearly using movementbased kernel density estimation method during July-August, between 2010 and 2014 (Benhamou and Cornélis 2010, Monsarrat et al. 2013). We estimated a "global" population home range, in a similar way to Vasilakis et al. (2016), by overlapping individual home ranges of 25 adult vultures (UD 95\% kernel), during July-August 2010-2011. With this method, each site could be part of the home range of one, several, or zero vulture(s). Hence, the global home range was computed as a proportion (on the basis of 25 birds tracked corresponding to $100 \%$ of the population) and gave a frequency index of vultures at each report site. The higher the frequency index at a report site, the more frequently vultures visited this site.

\section{Husbandry and quartering practices data}

To address the perception bias, we used indirect cues of farmer behaviour. We first investigated the usual mode of guarding and the presence (or absence) of a herder during the event, because a perception bias is more likely to occur when no witness was present when the animal dies and when vultures intervene (Morales-Reyes et al. 2017). If the herder was absent, the ranger asked about the frequency of visits to the herd along with the date of the last visit.

Because the familiarity with vultures and level of knowledge of their behaviour is certainly enhanced when farmers own a feeding station (Morales-Reyes et al. 2017), the ranger asked a complainant if he/she participated in the vulture feeding initiative (i.e. providing carcasses to supplementary feeding stations SFS), or if he/she had neighbours that do so. A network of SFS, provided with carcasses occurring naturally on farms, is widely distributed over the Grands Causses, and their number has doubled from c.50 in 2007 to c.10o in 2014 (Appendix S1). The biomass of carcasses deposited at SFS has been increased over the study period (2010-2014, no data before 2010) (Appendix $S_{3}$ ). On average in summer 2011 (middle of the study period), 8 tons of carcasses were available monthly at SFS (Fluhr et al. 2017).

\section{Data analysis}

The analysis was processed according to the two hypotheses and we used the complete dataset of reports, or a reduced dataset with vet assessments, depending on the question we addressed (see below). Statistical analyses were performed using SPSS v13 (SPSS 2004). Means are reported \pm SD. 
Table 1. Definition of the interaction factors of vultures with livestock, according to the state of the animal prior to vulture intervention, its level of mobility and its vital prognostic.

\begin{tabular}{|c|c|c|c|c|c|}
\hline \multicolumn{4}{|c|}{ State of the animal prior to vulture intervention } & \multicolumn{2}{|l|}{ Conclusion after vulture intervention } \\
\hline Alive / dead: & Level of mobility & Vital diagnostic & Vital prognostic & Intervention of vultures & $\begin{array}{l}\text { interaction factor } \\
\text { of vultures }\end{array}$ \\
\hline Dead & Null & Null & null & post-mortem: Vulture acted as scavenger & Quartering \\
\hline \multirow[t]{4}{*}{ Alive } & High & $\begin{array}{l}\text { Animal in good health, } \\
\text { or suffering from an }\end{array}$ & Favourable or light handicap. & $\begin{array}{l}\text { ante-mortem: animal injured by } \\
\text { vultures, cared, alive in fine. }\end{array}$ & Injury \\
\hline & & $\begin{array}{l}\text { accident that did not } \\
\text { necessitate urgent cares, } \\
\text { or suffering from a benign } \\
\text { pathology. }\end{array}$ & & $\begin{array}{l}\text { ante-mortem: the death of the } \\
\text { animal was mostly attributable } \\
\text { to vultures. }\end{array}$ & Primary \\
\hline & Moderate & $\begin{array}{l}\text { Animal suffering from } \\
\text { a severe accident, or } \\
\text { suffering from a } \\
\text { serious pathology. }\end{array}$ & $\begin{array}{l}\text { Moderate handicap or weakness; } \\
\text { uncertain vital prognostic in } \\
\text { the long term; would have } \\
\text { necessitated urgent cares. }\end{array}$ & $\begin{array}{l}\text { ante-mortem: Vultures have had } \\
\text { aggravated a situation, degrading } \\
\text { the animal health state, eventually } \\
\text { leading to its death. }\end{array}$ & Aggravating \\
\hline & Low & $\begin{array}{l}\text { Animal in bad health, } \\
\text { suffering from a severe } \\
\text { accident, or suffering from } \\
\text { a serious pathology. }\end{array}$ & $\begin{array}{l}\text { Unfavourable in the short term; } \\
\text { high probability of death in } \\
\text { the short term, even if urgent } \\
\text { cares would have been provided. }\end{array}$ & $\begin{array}{l}\text { ante-mortem: Vultures have had a } \\
\text { minor role, accompanying or } \\
\text { anticipating animal's certain death, } \\
\text { even without vulture's intervention. }\end{array}$ & Ancillary \\
\hline
\end{tabular}

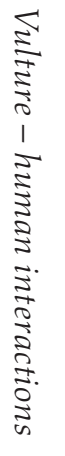




\section{Hypothesis 1: change in vulture behaviour}

First, we used a reduced dataset of 82 reports with vet assessment, corresponding to 58 report sites (since 14 reports concerned several animals that died at a given farm). The analysis was performed in four steps. (I) It was evaluated whether vultures intervened or not (other species are not concerned). If so, (2) the timing of vulture interventions was assessed, depending on whether the consumption was performed on a dead (post-mortem) or live (ante-mortem) animal. In the latter case, (3) the interaction factor of vultures was evaluated as a primary, aggravating, ancillary or injury. (4) The cause of death was evaluated, when possible. While data analysis was mostly descriptive because of a low sample size and the absence of a group of control, we used $\chi^{2}$ tests in contingency tables to compare the occurrence of ante-mortem vs post-mortem consumption relative to livestock species or between years, when possible.

Second, we examined the correlation between the vulture population trend (based on the number of breeding pairs annually) and movements (home range) of the 25 tagged birds, and the spatio-temporal distribution of the reports $(n=156)$, using Pearson correlations. We then tested if the mean yearly frequency index (see above) was correlated with the annual number of reports using Pearson correlation tests.

\section{Hypothesis 2: perception bias of conflict}

We considered that familiarity with vultures was an indirect clue to perception of conflict with vultures and was determined by the participation of farmers in the management of SFS or the proximity to other SFS in the neighbourhood. We thus analysed the proportion of farmers owning an SFS and the mean distance between the report and the nearest SFS. Second, we considered that farmers living close to vulture colonies have a better knowledge of vulture behaviour, due to regular personal observations and long-time experience (Morales-Reyes et al. 2017). Thus we calculated the mean distance between the centre of the vulture colonies (see above) and each report site. It was also necessary to describe the spatial extension of reports year after year by estimating the minimum convex polygon (MCP) that encompassed all report sites annually, in order to compare it with the annual extant of the global vulture home range. Third, farmers could gain knowledge about vulture behaviour through information letters and education activities that were mostly organised within protected areas (Appendix $\mathrm{S}_{4}$ ). We estimated the proportion of reports recorded in the protected areas, under the hypothesis that perception of conflict would be less biased in protected areas.

Because farmers may become more familiar and more informed about vultures year after year, we tested the temporal variation of all these parameters of familiarity, over the study period (2007-2014), using correlation tests and ANOVA.

Because perception biases are more likely to occur when no witness was present when an animal dies, we estimated the proportion of reports when the herdsman was present at the time of the death of the animal.

\section{Results}

Eighty-eight out of the 156 reports concerned sheep (56.4\%), but also a high proportion of cattle $(n=66,42.3 \%)$ and two cases of horses (1.3\%). In sheep, $71.6 \%$ of the animals were older than one year while in cattle, $68.2 \%$ of animals were less than one year old, among which $44 \%$ were new-born individuals (Appendix $\mathrm{S}_{5}$ ).

The temporal distribution of the 156 reports was not uniform across years $\left(\chi^{2}=73.43, \mathrm{df}=7\right.$, $P<0.001$; Figure 1a). After a few reports $(<5)$ in 2007-2008, the number of reports strongly increased between 2009 and 2011 (up to 40 reports annually) and decreased from 2012 to 2014. The spatial distribution of reports expanded over time $\left(\mathrm{R}^{2}=0.65, \mathrm{df}=7, P=0.015\right.$; Figure 2$)$. In 2007-2008, reports were concentrated within an area of $140 \mathrm{~km}^{2}$ and rapidly extended to an area $>3,500 \mathrm{~km}^{2}$, with two peaks over 6,500 km² in 2010 and 2013-2014 (Figure $1 \mathrm{c}$ ). 

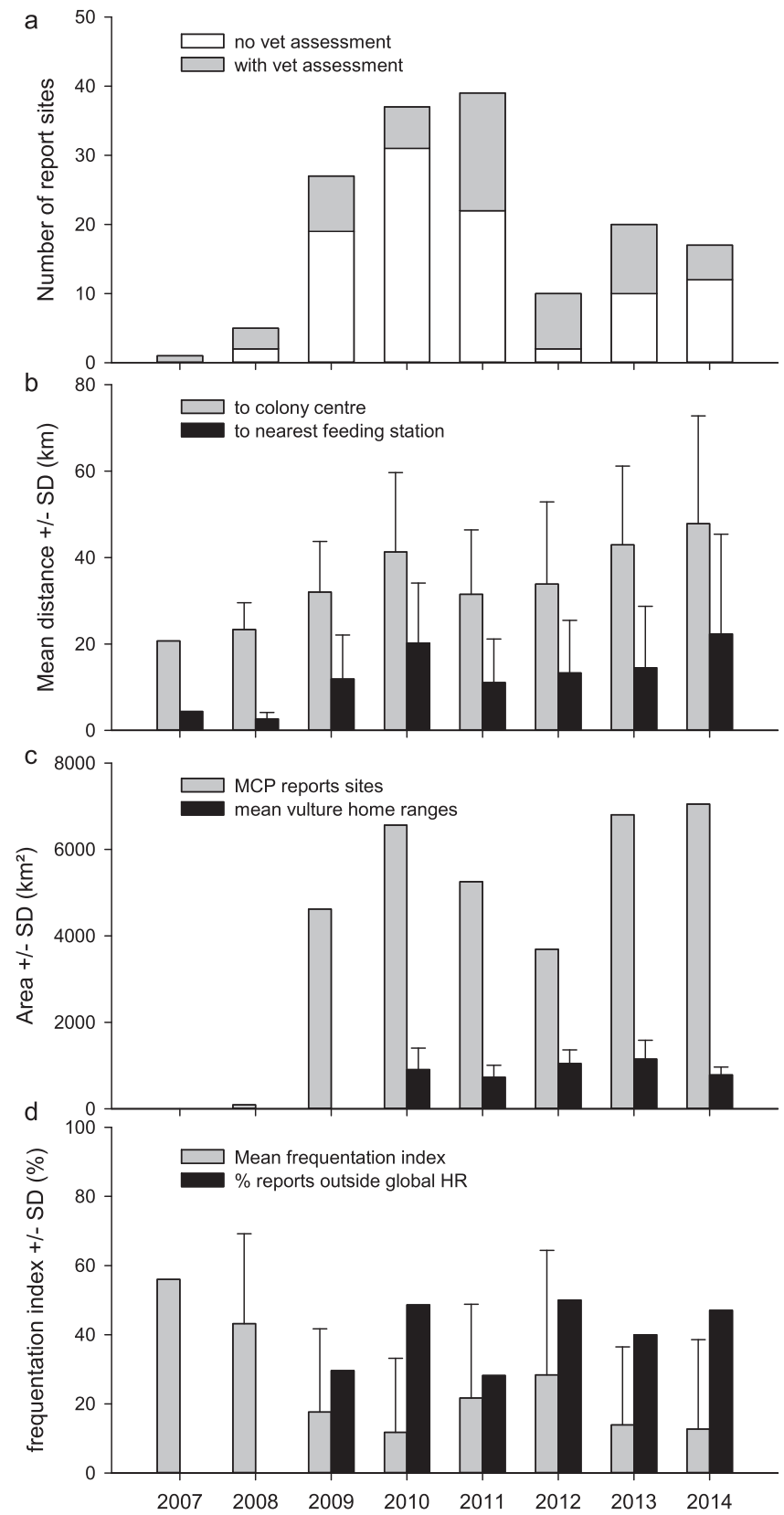

Figure 1. Annual distribution of a) the report sites analysed in the Grands Causses, distinguishing reports with and without vet assessment ( $n=156$ reports); b) mean distances of the report sites to the vulture colony centre and to the nearest supplementary feeding station (SFS); c) the area encompassing all the reports sites (estimated with minimum convex polygon) and mean home range of vultures tracked with GPS between 2010 and 2014; and d) mean frequentation index by vultures (an index value of $20 \%$ means that the site is located in the home range of $20 \%$ of vultures) and \% of reports located outside vultures' global home range. 


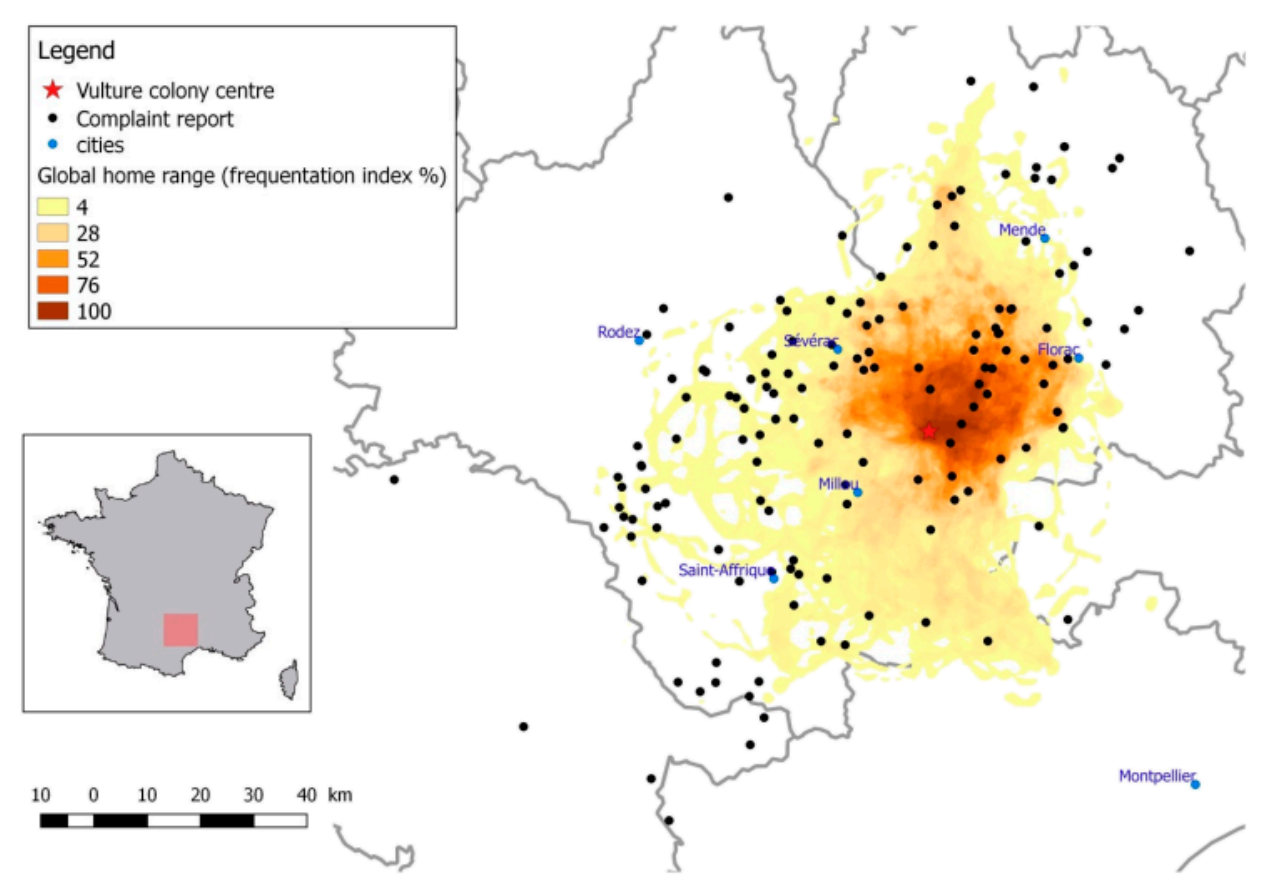

Figure 2. Map showing reports of vulture interactions with livestock (black dots) between 2007 and 2014, in relation to the vulture frequency index (the darker coloured areas correspond to places visited by most of the GPS-tracked individuals during summer 2010-2011). The star indicates the centre of vulture colonies.

\section{Hypothesis 1: change in vulture behaviour}

\section{The role of vultures}

Among 82 reports including a vet assessment, vultures intervened in 63 cases (76.8\%) (Table 2). Among these 63 cases, vet assessments concluded that vultures consumed the animal postmortem in 42 cases $(66.7 \%$ ) and ante-mortem in 15 cases (24\%) (Table 2). No reliable conclusion could be obtained for 6 cases $(9.5 \%)$. When considering the four years with more than to vet assessments (2009, 2011, 2012, 2013), the proportion of consumption ante-versus post-mortem did not differ between year $\left(\chi^{2}=1.198, \mathrm{df}=3, P=0.753\right)$. Vultures were never determined as a primary factor in the livestock mortality, and their role could not be determined in two cases out of 15 . In seven cases $(46.7 \%)$, vultures played an ancillary role, accompanying the animal death (Table 1 ). In three cases (20\%), vultures aggravated the health situation of the animal. In three other cases, the role of vultures was limited to non-serious injuries (i.e. superficial injuries made with the beak but without consequence for the animal's viability).

The 57 vet assessments with a valid conclusion concerned $71.9 \%$ of sheep and $28.1 \%$ of cattle. The proportion of cases of consumption ante-versus post-mortem did not differ between both livestock species $\left(\chi^{2}=0.279, \mathrm{df}=1, P=0.739\right)$. No apparent difference was found between sheep and cattle in the distribution of the interaction factors of vultures in ante-mortem interactions $\left(\chi^{2}\right.$ statistics not possible due to low sample size; $n=15)$, except for the injury factor that only concerned sheep.

The main causes of mortality were attacks from canids (dogs or wolves: $21 \%$ ) and pathological problems related to the animal's birth (the new-born or its mother: $18 \%$ ) (Table 2). The secondary causes were food-related (enterotoxaemia and toxins) (11\%), injury (fall and fracture) $(9 \%)$, pathology $(5 \%)$ or sudden death $(4 \%)$. The cause of mortality could not be identified for $24 \%$ of 
Table 2. Summary of conclusions of 82 reports with vet assessment. The table is organised according to the four questions that drive the vet assessment: 1 . Was there an intervention by vultures? 2. Was it consumption ante- or post-mortem? 3. What was the interaction factor of vultures? 4 . What was the cause of death of the animal or the cause of arrival of vultures (attraction factor)?

\begin{tabular}{|c|c|c|c|c|c|c|}
\hline & Yes & & & No & Not assessable & Total \\
\hline \multicolumn{7}{|c|}{ 2. Consumption by vultures } \\
\hline 3. Interaction factor & Post-mortem & Ante-mortem & Not assessable & & & \\
\hline Quartering & 42 & & & & & 42 \\
\hline Primary & & o & & & & o \\
\hline Aggravating & & 3 & & & & 3 \\
\hline Ancillary & & 7 & & & & 7 \\
\hline Injury & & 3 & & & & 3 \\
\hline Not assessable & & 2 & 6 & 15 & 4 & 27 \\
\hline \multicolumn{7}{|c|}{ 4. Cause of death/attraction } \\
\hline Attack of canids & 11 & & & 5 & 1 & 17 \\
\hline Problem of parturition & 8 & 5 & 1 & 1 & & 15 \\
\hline Enterotoxaemia & 8 & 1 & & & & 9 \\
\hline Injury & & 2 & & 5 & & 7 \\
\hline Disease & 3 & & & & 1 & 4 \\
\hline Sudden death & 2 & & 1 & & & 3 \\
\hline Dead animal nearby & & 2 & & 3 & & 5 \\
\hline Placenta consumed & & 2 & & & & 2 \\
\hline No answer & 10 & 3 & 4 & 1 & 2 & 20 \\
\hline Total & 42 & 15 & 6 & 15 & 4 & 82 \\
\hline
\end{tabular}

the vet assessments. In all cases, a loss of mobility (temporary or permanently) of the animal on which vultures intervened was determined. The presence of another dead animal nearby $(6 \%$ of the cases) or a placenta following birth $(2 \%)$ were the two main factors that most likely attracted vultures in the cases of injury factor or when vultures did not intervene.

\section{Relationship with vulture populations}

Temporal variations in the number of reports were not correlated with variations in vulture population size (linear regression: $\mathrm{R}^{2}=0.036, \mathrm{~F}_{1,6}=0.229, P=0.649$; Figure 3 ). Vulture population size was multiplied by 2.4 and increased regularly between 2007 ( 183 pairs) and 2014 (443 pairs), while the number of reports increased until 2011 and then decreased (Figure 1a).

From the individual home range of the 25 vultures tracked, we observed a modest increase ( $x$ 1.3) of home range area during the period 2010-2013, $\left(R^{2}=0.023, d f=4, P=0.071\right.$ ) (Figure Ic). The correlation between the home range area of individual vultures and the number of reports during these five years was not significant $(R$ Pearson $=-0.557 ; P=0.329)$. Furthermore between 2010 and 2014, the MCPs encompassing all reports sites were on average $85 \%$ larger than the individual vulture home range (Figure 1c), indicating that reports were spread over an area much larger than the area commonly used by individual vultures.

Using the population global home range, we attributed a vulture frequency index to each report site (Figure 2). On average, reports were located within the home range of $18.0 \pm 25.6 \%$ of vultures. $37.2 \%$ of the report sites $(n=58$ cases among 156$)$ were not included within the population home range (Figure $\mathrm{Id}$ ), i.e. were located outside the area where $95 \%$ of vulture locations were concentrated. This frequency index significantly decreased (divided by 4.6) across years $\left(\mathrm{R}^{2}=0.54, \mathrm{df}=7, P=0.037\right)$ whereas the percentage of reports located outside the global home range increased $\left(R^{2}=0.65\right.$, $\mathrm{df}=7, P=0.015$; Figure $1 \mathrm{~d}$ ). The annual number of report sites was negatively correlated with the 


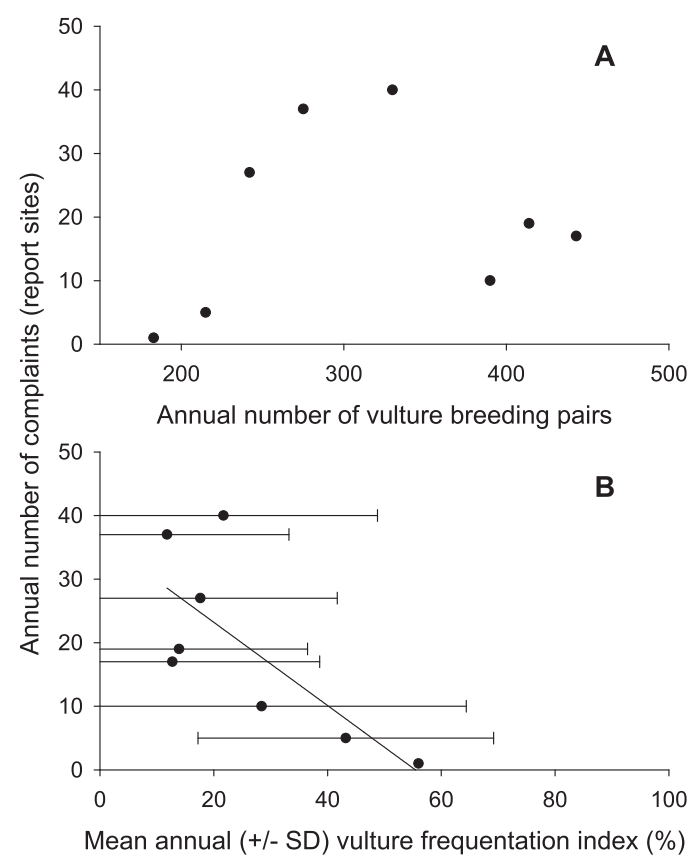

Figure 3. Relationship between the annual number of complaints (corresponding to report sites) and (A) the annual variation of the number of breeding pairs of Griffon Vultures in the Grands Causses; and (B) the mean \pm SD annual vulture frequency index.

mean frequentation index $\left(\mathrm{R}^{2}=0.56, \mathrm{df}=7, P=0.032\right.$; Figure $\left.3 \mathrm{~b}\right)$, but was not correlated with the annual biomass of carcasses available at SFS between 2010 and $2014\left(\mathrm{R}^{2}=0.52, \mathrm{df}=4, P=0.169\right)$.

\section{Hypothesis 2: perception bias of conflict}

\section{Familiarity with vultures}

On the 156 reports, only 10\% of complaining farmers owned an SFS. The mean distance between each report site and the nearest SFS was $14.2 \pm 14.1 \mathrm{~km}($ range $=0.23-78.3 \mathrm{~km}$, median $=10 \mathrm{~km})$. This distance tended to increase ( $\mathrm{x}$ 5) between 2007 and $2014\left(\mathrm{~F}_{1,154}=3.42, P=0.066\right.$; Figure $\mathrm{Ib}$ ). The mean distance between the report sites and the centre of vulture colonies was $36.9 \pm 18.0 \mathrm{~km}$ $($ range $=4.5-99.8 \mathrm{~km}$, median $=34.6 \mathrm{~km})$. This distance significantly increased and was multiplied by 2.3 between 2007 and $2014\left(\mathrm{~F}_{1,154}=9.39, P=0.003\right.$; Figure $\left.\mathrm{Ib}\right)$. When combining all years, $40.4 \%$ of the reports $(n=63)$ were located outside a protected area.

On the 57 cases where a conclusion could be assessed by a vet, the geographical situation of reports with ante-mortem consumption did not differ from the one of post-mortem cases (Table 3 ).

\section{Witness to vulture - livestock interactions}

Only seven reports among $156(4.5 \%)$ recorded the continuous presence of a herder at the time of vulture intervention. The herd was usually visited every day in $28.2 \%$ of cases $(n=44)$ but only once a week in $4.5 \%$ of cases $(n=7)$ and at irregular intervals (without further precision) in $46.5 \%$ of cases $(n=74)$. There was no data in $15.4 \%$ of cases $(n=24)$.

Among the 82 reports including vet assessments, there was no witness in the 19 cases where no vultures intervened (Table 2). On the 57 cases where a conclusion could be assessed, the 
Table 3. Cross-comparison of the geographical situation, ownership of supplementary feeding station (SFS) and presence of herdsman (as indirect cues for familiarity with vultures) for the reports where vultures intervene ante-mortem and post-mortem $(n=57$ reports with vet assessment).

\begin{tabular}{|c|c|c|c|c|c|c|c|}
\hline & & $\begin{array}{l}\text { ante-mortem } \\
(n=15)\end{array}$ & $\begin{array}{l}\text { post-mortem } \\
(n=42)\end{array}$ & test & value & df & $\mathrm{p}$ \\
\hline $\begin{array}{l}\text { Distance to centre of vulture } \\
\text { colonies }(\mathrm{km})\end{array}$ & & $27.31 \pm 14.77$ & $32.12 \pm 17.71$ & t-test & 0.940 & 55 & 0.351 \\
\hline Distance to the nearest SFS $(\mathrm{km})$ & & $5.83 \pm 8.08$ & $8.86 \pm 10.32$ & t-test & 1.030 & 55 & 0.307 \\
\hline Vulture frequentation index (\%) & & $38.67 \pm 21.73$ & $24.76 \pm 24.82$ & t-test & -1.920 & 55 & 0.060 \\
\hline \multirow[t]{2}{*}{ Report in protected area } & Yes & 8 & 27 & \multirow[t]{2}{*}{$\mathrm{Chi}^{2}$} & \multirow[t]{2}{*}{0.559} & \multirow[t]{2}{*}{1} & \multirow[t]{2}{*}{0.454} \\
\hline & No & 7 & 15 & & & & \\
\hline \multirow[t]{2}{*}{ Owner of SFS } & Yes & 4 & 6 & \multirow[t]{2}{*}{$\mathrm{Chi}^{2}$} & \multirow[t]{2}{*}{1.171} & \multirow[t]{2}{*}{2} & \multirow{2}{*}{0.279} \\
\hline & No & 11 & 36 & & & & \\
\hline \multirow[t]{3}{*}{ Presence of herdsman } & Yes & 2 & 6 & \multirow[t]{3}{*}{$\mathrm{Chi}^{2}$} & \multirow[t]{3}{*}{0.379} & \multirow[t]{3}{*}{2} & \multirow[t]{3}{*}{0.827} \\
\hline & No & 13 & 35 & & & & \\
\hline & No data & $\mathrm{o}$ & 1 & & & & \\
\hline
\end{tabular}

proportion of cases where herdsman was present was similar between ante-mortem and postmortem cases (Table 3).

\section{Discussion}

This detailed analysis over eight years revealed a very low incidence of interactions between vultures and livestock in the Grands Causses, compared to other causes of mortality (see below). The outcome of this study can reveal important facts about vulture-livestock conflict and help find options to mitigate similar conflict that may occur in other parts of the world.

Most results did not support the behavioural change hypothesis but rather supported the perception bias hypothesis. The main result was that vultures intervened post-mortem in most cases, in accordance with their natural scavenging role, and consumed animals already dead following problems with birth and food, or attacks by canids mainly, as found in the Pyrenees (Arthur and Zenoni 2010). As for the rare interventions ante-mortem, vultures never played a primary role in the death of the animal. They rarely acted as an aggravating factor but generally as an ancillary factor on an animal close to death. Secondly, the annual number of reports was not correlated with the vulture population trend (increasing) and reports were not more numerous in the areas the most intensively used by vultures. The hypothesis of food shortage for vultures is very unlikely given the very high and stable breeding success and increasing food resource available at feeding stations (see below). Since reports were mostly located at large distance from vulture colonies, at the periphery of individual home ranges, away from SFS, outside of protected areas, and generally without a direct witness of the interaction, our results better support the perception bias hypothesis, most likely to be related to a lack of knowledge about the natural behaviour of vultures.

\section{Did vultures become predators?}

Cases of interventions ante-mortem did occur but remained exceptional. Rarely, the animal was still alive at the time of the vet assessment, only lightly injured after having received a superficial beak bite that constitutes a sort of "mortality test" by vultures. This proves that animals in good health, able to walk, have no difficulty in "escaping" from vultures and are not threatened by them. On the other hand, all other animals consumed ante-mortem were already immobile when vultures arrived, and immobility is very likely to be a strong stimulus for scavengers that would trigger consumption. 
The scientific literature reported exceptional ante-mortem intervention by Gyps vultures more than 100 years ago in Europe (Miégemarque 1902 cited in Choisy 2014), but also in Africa (Houston 1974). In North America, on rare occasions, Black Vultures Coragyps atratus are known to target injured and condemned cattle, often new-born (Mueller and Berger 1967, Avery and Cummings 2004; Humphrey et al. 2004). Some species of vultures are also known to kill small animals, such as the Cinereous Vulture Aegypius monachus killing sick rabbits, or Bearded Vultures Gypaetus barbatus killing tortoises (Donázar 1993). It is therefore wrong to publicise a recent change in vulture foraging and feeding behaviour to become predators. Indeed vultures evolved from predator ancestors to specialised scavengers by losing their ability to kill prey with sharp claws and powerful toes, and their morphology acquired during 20 million years cannot be changed within a few years (Campbell 2015). Actually the only behavioural changes which were scientifically demonstrated since 2000 are related to a decrease in flight distance towards humans (Zuberogoitia et al. 2010) and a diversification in Griffon Vulture diet, including smaller carcasses and butchery by-products (Donázar et al. 2010). However, these behavioural changes happened in a particular context in Spain, where the political and technical consequences of the bovine spongiform encephalopathy (BSE) crisis led authorities to shut many SFS between 2006 and 2011, resulting in a sudden and massive food shortage for vultures $(80 \%$ reduction in the number of carcasses available) (Camiña and Montelio 2006, Donázar et al. 2009, 2016) (see below). In other words, the apparent behavioural change by vultures in Spain mostly reflected changes in food availability due to changes in farming husbandry practices (Donázar et al. 2009, Margalida et al. 2014). No such food shortage occurred in France, where the number of carcasses available at SFS actually increased in the years $2000-2010$.

\section{Relationship with vulture population trends and spatial distribution}

The temporal distribution of reports was not correlated with vulture population trend. Therefore, the causes of the interactions between livestock and vultures were not linked with any density-dependent regulation process that could have led some starving vultures to interact with domestic ungulates if the carrying capacity of the ecosystem had been reached. There was no evidence that vultures in the Causses were in a difficult situation regarding food resources, since their breeding success remained stable with values of $75-80 \%$ over the 8 -year study period (unpubl. data from Comite interdépartemental Vautours-Elevage), close to values recorded in other stable natural populations (Leconte and Som 1996). In comparison, when food resources abruptly drop, as was the case in Spain during the BSE crisis, Griffon Vultures responded partly by switching diet (Donázar et al. 2010), partly by dispersal (increased trend in France in occurrence of vultures previously ringed in Spain after 2006; authors' unpubl. data), but more importantly by postponing reproduction. Indeed many Griffon Vultures breeding in the French Pyrenees used to forage in neighbouring Spain before 2006, and during the BSE crisis (2006-2011) the breeding success of vultures in the French Pyrenees strongly declined from $75 \%$ to $<30 \%$ (Duriez and Peyrusqué unpubl. data). Such a demographic response in favour of adult survival at the expense of current reproductive output in difficult years is expected from life history theory for long-lived birds (Stearns 1992). In France, there was no evidence of food switching during the BSE period, as Griffon Vultures were never observed feeding on anything other than carcasses of large ungulates (no chickens, no road-killed animals, never in garbage dumps). Finally, the impact of the BSE crisis in the Causses was probably minor and indirect, since adult vultures tagged in the Causses were never observed in Spain and hardly ever in the Pyrenees (authors' unpubl. data from long term tracking and ring resightings).

The confrontation between the spatial distribution of reports and the spatial use of vultures did not support the hypothesis of change in vulture behaviour, which predicted that most vulture interactions (complaint reports) should occur in areas used most intensively by vultures. First, the area covered by reports progressively widened over the years, with an increasing number of reports located at the periphery of the global home range of vultures and not in the areas most 
intensively used by vultures, close to the colonies. Second, report sites were located on average 37 $\mathrm{km}$ away from the vultures' activity centre (reintroduction site, where most vultures breed and roost), and this distance increased over the years. This phenomenon was corroborated by the gradual decrease of the mean frequency index of vultures at report sites over the years, indicating that report sites were included within the home range of fewer and fewer vultures over time. Therefore, the majority of the reports occurred in places away from vulture activity centres, i.e. in areas that individual vultures visit infrequently, or only recently. A similar observation was made in the Pyrenees where many reports occurred in areas rarely visited by vultures prior to 2007 (Arthur and Zenoni 2010).

Spiegel et al. (2013) have shown that hungry vultures increase their foraging movements compared to satiated birds, hence it can be argued that birds prospecting further from the colony may be food deprived and would be more prone to risk killing an animal alive. The cross-comparison of the characteristics of report sites where true ante-mortem consumption occurred vs post-mortem cases revealed no significant difference, except for the vulture frequency index, that was slightly higher for ante-mortem cases (Table 3). This means that the probability of an ante-mortem event was not higher further from the colonies (only the complaints were more and more distant from the colonies through time, not ante-mortem cases that are scattered throughout the study area), thus invalidating this hypothesis of starving individuals that forage farther and initiate ante-mortem events. Yet it cannot be excluded that the initiation of ante-mortem consumption could be due to a few hungrier individuals, whatever the distance to the colony.

\section{Perception bias on vulture behaviour: Importance of communication, education and rumour}

According to the statements by complaining farmers, livestock was mostly unattended at the time of interactions with vultures, but generally confined inside enclosures, not directly adjacent to the farms. Many herds were visited irregularly, every day or every week. Therefore, in most cases, nobody was present at the start of the intervention by vultures. The complainant generally arrived on site after the vultures and when they had already started to feed, or were perched or flying in the vicinity of the injured or dead animal.

Why did half of the vet assessments actually concern post-mortem cases? Cross-comparison between farmers with ante- and post-mortem cases did not differ in geographical location features and husbandry practices, taken as indirect cues of familiarity with vultures and witness of vulture - livestock interactions. The answer is probably related to the spectacular behaviour of vultures while searching for carcasses and feeding. Griffon Vultures often arrive in a few minutes and gather in large groups of more than 50 individuals on ungulate carcasses (Cramp and Simmons 1980, Bosè et al. 2012). A group of c.100 vultures can consume an adult sheep in 20 minutes, whose carcass is generally hidden by vultures when they feed (Duriez et al. 2012, Cortes-Avizanda et al. 2014).

These behavioural traits of vultures can easily be misunderstood by people who have not been informed about their ecology. In the Causses, information about vultures is mainly provided to farmers and the general public by local NGOs (meetings in villages close to vulture colonies) and by park authorities via information letters (only for inhabitants of the parks). Yet we found that $40 \%$ of reports occurred outside these protected areas, thus in places where no reliable information about vultures was disseminated. Moreover, farmers who work with vultures to dispose of carcasses via an SFS, regularly receive specific information about vultures, and may develop personal knowledge and experience by observing these birds. In Spain, a large-scale survey of farmers' perception of scavengers revealed that a positive attitude was driven by personal experience with vultures and local ecological knowledge (Morales-Reyes et al. 2017). Since the majority of complaining farmers were located outside the MCP including the SFS, and did not own an SFS, it is therefore likely that most of them did not receive any reliable information about vulture 
feeding behaviour, and their main source of information was probably newspapers, TV, the internet and word-of-mouth.

The vulture-livestock conflict reported here resembles other scavenger-livestock conflicts elsewhere in the world, where people tend to blame scavengers even though it is difficult to identify the cause of livestock death. The White-tailed Eagle Haliaeetus albicilla and Bald Eagle Haliaeetus leucocephalus are facultative scavengers often accused of killing lambs, but these accusations have been proved to be overestimated, since most of the lamb remains found in eagle nests actually came from carcasses that were scavenged (Marr et al. 1995, Love 2013). In Norway, the perception of lamb attacks by White-tailed Eagles was stronger in the south of the country (where eagles had been extirpated and then recently returned naturally), than in the north (where eagles never disappeared and where farmers considered these birds as harmless (Willgohs 1961 in Love 2013). These examples illustrate the importance of familiarity with the species in human perceptions of human-wildlife conflicts, which are particularly intense and overestimated in areas where predators have disappeared and are returning (Woodroffe et al. 2005).

\section{Conclusion}

This large-scale analysis of complaints of interactions between vultures and livestock in the Grands Causses revealed a very low occurrence of ante-mortem interventions of vultures (15 cases occurring over eight years, i.e. two cases per year on average). Such a number is negligible compared to the c.40,0oo livestock that die every year in the region and would represent $<0.01 \%$ of the total livestock mortality (unpubl. data from Comité interdépartemental Vautours-Elevage 2018). The 'perception bias hypothesis' appears to be more likely than a change in vulture behaviour. It seems important for conservationists to improve and/or adapt communication and information towards both farmers and the general public about the natural behaviour of vultures (Morales-Reyes et al. 2017). A continuous effort must be made by conservationists to educate people about vultures, their benefits to farmers as natural and efficient scavengers (Dupont et al. 2012, O'Rourke 2014, Morales-Reyes et al. 2015), and about ways to limit potential interactions with livestock that are most vulnerable (e.g. close monitoring of births, maintaining indoors sick animals with reduced mobility, etc.). Communication actions must be planned in the long term and must be proactive by educating people from regions where vultures recently returned or are expected to return in the near future, naturally or via reintroduction.

\section{Supplementary Material}

To view supplementary material for this article, please visit https://oi.org/10.1017/ So959270918000345

\section{Acknowledgements}

We thank all agents of the PNC, ONCFS, and the veterinary surgeons of the Fédération des Groupements Techniques Vétérinaires du Languedoc-Roussillon who participated in the reports and vet assessments. We thank Dr V. Zénoni for advice on the definition of vet assessment protocols; F. Cloup, N. Ziletti, P. Lécuyer, T. David (LPO); P. Boudarel (DREAL LanguedocRoussillon, funding reports and vet assessments), D. Aka and X. Meyrueix (DDCSPP48), D. Bugaud (DDT48). Vulture GPS tracking was made possible by the involvement of W. Bouten, G. Dell'Omo, S. Benhamou, C. Bessa-Gomes and F. Sarrazin and funded by ANR project SoftPop. This work would not have been possible without the agreement of the Comite interdépartemental Vautours-Elevage, presided over by Mr le Préfet de Lozère. 


\section{References}

Arthur, C. P. and Zenoni, V. (2010) Les dommages sur bétail domestique attribués au vautour fauve, Tarbes: Parc National des Pyrénées.

Avery, M. L. and Cummings, J. L. (2004) Livestock depredations by Black Vultures and Golden Eagles. Sheep and Goat Research Journal 19: 58-63.

Benhamou, S. and Cornélis, D. (2010) Incorporating movement behavior and barriers to improve kernel home range space use estimates. J. Wildl. Manage. 74: 1353-1360.

Bennett, N. J. (2016) Using perceptions as evidence to improve conservation and environmental management. Conserv. Biol. 30 : 582-592.

Bosè, M., Duriez, O. and Sarrazin, F. (2012) Intra-specific competition in foraging griffon vultures: 1 . The dynamics of feeding in groups. Bird Study 59: 182-192.

Camiña, A. (1995) Attacks on livestock by Eurasian griffons in Northern Spain. J. Raptor Res., 29: 214.

Camiña, A. and Montelio, E. (2006) Griffon Vulture Gyps fulvus food shortages in the Ebro Valley (NE Spain) caused by regulations against Bovine Spongiform Encephalopathy (BSE). Acta Ornithol. 41: 7-13.

Campbell, M. O. (2015) Vultures, their evolution, ecology and conservation. Boca Raton, Florida, USA: CRC Press.

Cavalcanti, S., Marchini, S., Zimmermann, A., Gese, E. M. and Macdonald, D. W. (2010) Jaguars, livestock, and people in Brazil: realities and perceptions behind the conflict. Pp. 383-402 In D. Macdonald and A. J. Loveridge, eds. The biology and conservation of wild felids, Oxford, UK: Oxford University Press.

Choisy, J. P. (2014) Le Vautour fauve Gyps fulvus et les dommages au bétail: analyse, objectifs, stratégie. Le Courrier de l'Environnement 64: 105-118.

Cortès-Avizanda, A., Donazar, J. A. and Pereira, H. M. (2015) Top scavengers in a wilder Europe. Pp. 85-106 In H. M. Pereira and L. M. Navarro, eds. Rewilding European landscapes, Cham: Springer International Publishing.

Cortes-Avizanda, A., Jovani, R., Donazar, J. A. and Grimm, V. (2014) Bird sky networks:
How do avian scavengers use social information to find carrion? Ecology 95: 1799-1808.

Cramp, S. and Simmons, K. E. L. (1980) Gyps fulous Eurasian griffon vulture. In S. Cramp and K. E. L. Simmons, eds. Handbook of the birds of Europe, the Middle East and North Africa, Vol. II. Oxford, UK: Oxford University Press.

Donázar, J.A. (1993) Los buitres ibéricos. Biología y conservación, Madrid: J. M. Reyero.

Donázar, J. A., Cortés-Avizanda, A., Fargallo, J. A., Margalida, A., Moleón, M., MoralesReyes, Z., Moreno-Opo, R., Pérez-Garcia, J. M., Sánchez-Zapata, J. A., Zuberogoitia, I. and Serrano, D. (2016) Roles of raptors in a changing world: from flagships to providers of key ecosystem services. Ardeola 63: 181-234.

Donázar, J. A., Margalida, A. and Campion, D. (2009) Vultures, feeding station and sanitary legislation: a conflict and its consequences from the perspective of conservation biology. Donostia: Aranzadi Sociedad de ciencias.

Donázar, J., Cortés-Avizanda, A. and Carrete, M. (2010) Dietary shifts in two vultures after the demise of supplementary feeding stations: consequences of the EU sanitary legislation. Eur. J. Wildl. Res. 56: 613-621.

Dupont, H., Mihoub, J. B., Bobbé, S. and Sarrazin, F. (2012) Modelling carcass disposal practices: implications for the management of an ecological service provided by vultures. J. Appl. Ecol. 49: 404-411.

Duriez, O. and Issa, N. (2015) Vautour fauve Gyps fulvus. Pp. $382-385$ in N. Issa and Y. Muller, eds., Atlas des oiseaux de France métropolitaine. Nidification et présence hivernale, Vols. 1-2. Paris: LPO / SEOF / MNHN. Delachaux and Niestlé.

Duriez, O., Herman, S. and Sarrazin, F. (2012) Intra-specific competition in foraging griffon vultures: 2 . the influence of supplementary feeding management. Bird Study 59: 193-206.

Fluhr, J., Benhamou, S., Riotte-Lambert, L. and Duriez, O. (2017) Assessing the risk for an obligate scavenger to be dependent on predictable feeding sources. Biol. Conserv. 215: 92-98. 
Gangoso, L., Agudo, R., Anadón, J. D., de la Riva, M., Suleyman, A. S., Porter, R. and Donázar, J. A. (2013) Reinventing mutualism between humans and wild fauna: insights from vultures as ecosystem services providers. Conserv. Lett. 6: 172-179.

Goldstein, I., Paisley, S., Wallace, R., Jorgenson, J. P., Cuesta, F. and Castellanos, A. (2006) Andean bear-livestock conflicts: a review. Ursus 17: 8-15.

Houston, D. C. (1974) Food searching in griffon vultures. East African Wildl. J. 12: 63-77.

Humphrey, J. S., Tillman, E. A. and Avery, M. L. (2004) Vulture-cattle interactions at a Central Florida Ranch. USDA National Wildlife Research Center - Staff Publications. 344. https://digitalcommons. unl.edu/icwdm_usdanwrc/344.

Leconte, M. and Som, J. (1996) La reproduction du vautour fauve Gyps fulvus dans les Pyrénées occidentales: historique d'une restauration d'effectifs et paramètres reproducteurs. Alauda 64: 135-148.

Love, J. (2013) A saga of Sea Eagles, Caithness, UK: Whittles publishing.

Margalida, A., Campion, D. and Donazar, J. A. (2011) European vultures' altered behaviour. Nature 480: 457.

Margalida, A., Campion, D. and Donazar, J. A. (2014) Vultures vs livestock: conservation relationships in an emerging conflict between humans and wildlife. Oryx 48: 172-176.

Marr, N. V., Edge, W. D., Anthony, R. G. and Valburg, R. (1995) Sheep carcass availability and use by Bald eagles. Wilson Bull. 107: 251-257.

Moleón, M., Sanchez-Zapata, J.A., Gil-Sanchez, J. M., Barea-Azcon, J. M., BallesterosDuperon, E. and Virgos, E. (2011) Laying the foundations for a human-predator conflict solution: Assessing the impact of Bonelli's Eagle on rabbits and partridges. PLOS One 6(7): e22851.

Moleon, M., Sanchez-Zapata, J. A., Margalida, A., Carrete, M., Owen-Smith, N. and Donazar, J. A. (2014) Humans and scavengers: The evolution of interactions and ecosystem services. BioScience 64: 394-403.

Monsarrat, S., Benhamou, S., Sarrazin, F., Bessa-Gomes, C., Bouten, W. and Duriez, O. (2013) How predictability of feeding patches affects home range and foraging habitat selection in avian social scavengers? PLOS One 8(1): 553077.

Morales-Reyes, Z., Martín-López, B., Moleón, M., Mateo-Tomás, P., Botella, F., Margalida, A., Donázar, J. A., Blanco, G. Pérez, I. and Sánchez-Zapata, J. A. (2017) Farmer perceptions of the ecosystem services provided by scavengers: what, who and to whom. Conserv. Lett. II: 1-11. doi.org/10.1111/ conl.12392

Morales-Reyes, Z., Perez-Garcia, J. M., Moleon, M., Botella, F., Carrete, M., Lazcano, C.,Moreno-Opo, R.,Margalida,A., Donázar, J. A. and Sanchez-Zapata, J. A. (2015) Supplanting ecosystem services provided by scavengers raises greenhouse gas emissions. Science Reports 5: 7811.

Mueller, H. G. and Berger, D. D. (1967) Turkey vultures attack living prey. The Auk 84: 430-431.

Nyhus, P. J. (2016) Human-wildlife conflict and coexistence. Annu. Rev. Environ. Resour. 41: 143-171.

O'Rourke, E. (2014) The reintroduction of the white-tailed sea eagle to Ireland: People and wildlife. Land Use Policy 38: 129-137.

Redpath, S. M., Gutierrez, R. J., Wood, K. A. and Young, J. C., eds. (2015) Conflicts in conservation: navigating towards solutions. Cambridge, UK: Cambridge University Press. Spiegel, O., Harel, R., Getz, W. and Nathan, R. (2013) Mixed strategies of griffon vultures' (Gyps fulvus) response to food deprivation lead to a hump-shaped movement pattern. Movement Ecol. 1: 5.

SPSS (2004) SPSS Base 13.o User's guide, Chicago, USA: SPSS Inc.

Stearns, S. C. (1992) The evolution of life histories. Oxford, UK: Oxford University Press.

Terrasse, M., Sarrazin, F., Choisy, J. P., Clemente, C., Henriquet, P., Lecuyer, P., Pinna, J. L. and Tessier, C. (2004) A success story: the reintroduction of Eurasian griffon Gyps fulvus and Black Aegypius monachus vultures in France. Pp. 127-145 in R. D. Chancellor and B.-U. Meyburg, eds. Raptors worldwide. Budapest: WWGBP / MME.

Thorn, M., Green, M., Dalerum, F., Bateman, P. W. and Scott, D. M. (2012) What drives human-carnivore conflict in the North West Province of South Africa? Biol. Conserv. 150: $23-32$. 
Vasilakis, D. P., Whitfield, D. P., Schindler, S., Poirazidis, K. S. and Kati, V. (2016) Reconciling endangered species conservation with wind farm development: Cinereous vultures (Aegypius monachus) in southeastern Europe. Biol. Conserv. 196: 10-17.

Woodroffe, R., Thirgood, S. and Rabinowitz, A. (2005) People and wildlife, conflict or coexistence? Cambridge: Cambridge University Press.

Zuberogoitia, I., Martinez, J. E., Margalida, A., Gomez, I., Azkona, A. and Martinez, J. A. (2010) Reduced food availability induces behavioural changes in Griffon vulture Gyps fulvus. Ornis Fennica 87: 52-6o.

\section{OLIVIER DURIEZ*, JULIE FLUHR}

Centre d'Ecologie Fonctionnelle et Evolutive, UMR 5175 CNRS-Université de MontpellierEPHE-Université Paul Valery, 1919 Route de Mende, 34293 Montpellier cedex 5, France

\section{SANDRINE DESCAVES}

Parc national des Cévennes, 6 bis place du palais, 48400 FLORAC, France

\section{REGIS GALLAIS}

Office national de la Chasse et de la Faune Sauvage, 147 route de Lodève 34990 Juvignac, France

\section{RAPHAËL NEOUZE}

LPO Grands Causses, le bourg, 12720 Peyreleau, France

\section{FREDERIC DECANTE}

Fédération des Groupements Techniques Vétérinaires du Languedoc-Roussillon, Cabinet vétérinaire, Rue du Coulas, 48500 Banassac, France

*Author for correspondence; e-mail:olivier.duriez@cefe.cnrs.fr

Received 15 September 2017; revision accepted 25 September 2018; Published online 12 April 2019 